Jurnal Ilmiah Mahasiswa Kendali dan Listrik
Vol. 1, No. 2, Mounth 2020, page-page. 42 50
E-ISSN: 2723-598X
DOI: https://doi.org/10.33365/jimel.v1i1

\title{
PENGENDALIAN KUALITAS AIR PADA BUDIDAYA IKAN LELE JENIS MUTIARA
}

\author{
Rijal Nurhidayat \\ ${ }^{1}$ Program Studi S1 Informatika,Universitas Teknokrat Indonesia ${ }^{\mathbf{1}}$, \\ rizalnurhidayat111@gmail.com
}

\begin{tabular}{lll}
\hline Received: (date month year) & Accepted: (date month year) & Published : (date month year ) \\
\hline
\end{tabular}

\begin{abstract}
The catfish cultivated in the Dua Putra Catfish pond is a type of pearl catfish. Based on the results of interviews that the author has conducted with the owner of Two Son Catfish, Mr. Harry Supriyanto, the author concludes that Mr. Harry Supriyanto has experienced problems in cultivating Pearl catfish due to limited tools to measure the $\mathrm{pH}$ level of pond water and can control the quality of pond water that is used for cultivation. Pearl catfish. Pond owners can only estimate changes in water $\mathrm{pH}$ from the behavior of fish that often float on the surface of the water. This method is considered less effective for determining the $\mathrm{pH}$ level of water in the pond. a good $\mathrm{pH}$ level for catfish is 6 to 8 if less than 5 it will be very bad for catfish because it can cause mucus clots in the gills, while a pH above 8 can cause catfish appetite to decrease. According to the above problems, the author aims to develop or design a tool for controlling water quality in pearl type catfish culture as a tool that is expected to be able to monitor the $\mathrm{pH}$ quality of water in the Dua Putra Catfish pond and to control water quality to neutralize the $\mathrm{pH}$ of the pond water.
\end{abstract}

Keywords: PH tools, Water Control, Arduino, Pearl Catfish

\section{Abstrak}

Ikan lele yang dibudidayakan di kolam Ternak Lele Dua Putra adalah ikan lele jenis Mutiara. Bedasarkan hasil wawancara yang telah penulis lakukan kepada pemilik Ternak Lele Dua Putra Bapak Harry Supriyanto, penulis mendapatkan kesimpulan bahwa Bapak Harry Supriyanto mengalami kendala dalam membudidayakan ikan lele jenis Mutiara akibat terbatasnya alat untuk mengukur kadar $\mathrm{pH}$ air kolam serta dapat mengendalikan kualitas air kolam yang dijadikan pembudidayaan ikan lele jenis Mutiara ini. Pemilik kolam hanya bisa mengira-ngira perubahan $\mathrm{pH}$ air dari perilaku ikan yang sering mengambang di permukaan air. Cara tersebut diangap kurang efektif untuk menentukan kadar $\mathrm{pH}$ air di dalam kolam. kadar $\mathrm{pH}$ yang baik untuk ikan lele adalah 6 sampai 8 jika kurang dari 5 itu akan sangat buruk bagi ikan lele karena bisa menyebabkan penggumpalan lendir pada insang, sedangkan $\mathrm{pH}$ diatas 8 dapat menyebabkan nafsu makan ikan lele berkurang. Menurut dari permasalahan diatas, penulis bertujuan untuk mengembangkan atau merancang sebuah alat Pengendalian Kualitas Air Pada Budidaya Ikan Lele Jenis Mutiara sebagai alat yang diharapkan mampu untuk memonitoring kualitas $\mathrm{pH}$ air didalam kolam Ternak Lele Dua Putra serta dapat mengendalikan kualitas air untuk dapat menetralkan $\mathrm{pH}$ air kolam.

Kata Kunci : Alat pH, Pengendalian Air, Arduino, Ikan Lele Mutiara

\section{To cite this article:}

Rijal Nurhidayat. (2020). Pengendali Kualitas Air Pada Budiaya Ikan Lele Jenis Mutiara, Vol(1) No(2), 42-50. 


\section{PENDAHULUAN}

Ikan Lele merupakan ikan air tawar yang paling digemari oleh masyarakat, karena kemudahan dalam budidayanya dan harganya yang terjangkau, sehingga banyak pembudidaya ikan lele pemula yang memilih ikan ini sebagai komoditi andalan. Namun masih terdapat beberapa kendala dalam pembudidayaannya seperti kurang diperhatikannya kualitas air kolam sehingga kualitas benih ikan lele yang dihasilkan kurang maksimal.

Ikan lele yang dibudidayakan di kolam Ternak Lele Dua Putra adalah ikan lele jenis Mutiara. Bedasarkan hasil wawancara yang telah penulis lakukan kepada pemilik Ternak Lele Dua Putra Bapak Harry Supriyanto, penulis mendapatkan kesimpulan bahwa Bapak Harry Supriyanto mengalami kendala dalam membudidayakan ikan lele jenis Mutiara akibat terbatasnya alat untuk mengukur kadar $\mathrm{pH}$ air kolam serta dapat mengendalikan kualitas air kolam yang dijadikan pembudidayaan ikan lele jenis Mutiara ini. Pemilik kolam hanya bisa mengira-ngira perubahan $\mathrm{pH}$ air dari perilaku ikan yang sering mengambang di permukaan air. Cara tersebut diangap kurang efektif untuk menentukan kadar $\mathrm{pH}$ air di dalam kolam. kadar $\mathrm{pH}$ yang baik untuk ikan lele adalah 6 sampai 8 jika kurang dari 5 itu akan sangat buruk bagi ikan lele karena bisa menyebabkan penggumpalan lendir pada insang [1], sedangkan $\mathrm{pH}$ diatas 8 dapat menyebabkan nafsu makan ikan lele berkurang.

\section{TELAAH PUSTAKA}

Ikan lele janis mutiara merupakan jenis baru ikan lele afrika Clarias gariepinus Burchell, 1822 unggul hasil pemuliaan Badan Penelitian Ikan (BPPI) Sukamandi yang telah dinyatakan lulus pada penelitian Pelepasan Jenis/Varietas pada tanggal 27 Oktober 2014, dengan nama ikan lele MUTIARA (Mutu Tinggi Tiada Tara). Ikan lele Mutiara memiliki sifat keunggulan performa budidaya yang rlatif lengkap sesuai dengan yang diharapkan para petani ikan lele terutama pertumbuhan yang cepat, pakan yang lebih efisien, variasi ukuran yang rendah dan tahan terhadap penyakit [2]. Hasil penelitian pengaruh suhu terhadap ikan lele menunjukkan bahwa penggunaan pengering cabinet dryer dengan berbagai variasi suhu berpengaruh terhadap mutu kimia dendeng ikan lele dumbo yang dihasilkan, dimana suhu pengeringan terbaik adalah suhu 65oC, dengan kadar air sebesar 25,02\%,kadar protein sebesar 16,04\% dan kadar lemak sebesar 39,54\% [3].

\section{Analisis Parameter Pertumbuhan Ikan Lele}

Terdapat beberapa faktor yang mempengaruhi pertumbuhan ikan lele, faktor ini sangat melekat terhadap kelangsungan pertumbuhan ikan lele. Berikut beberapa faktor yang mempengaruhi pertumbuhan ikan lele:

\section{Derajat Kelangsungan Hidup (SR)}

Derajat kelangsungan hidup (Survival Rate) dihitung dengan menggunakan rumus:

$$
S R=\left(\frac{N t}{N o}\right) \times 100 \%
$$

Keterangan :

$$
\begin{array}{ll}
\mathrm{SR} & =\text { Kelangsungan hidup }(\%) \\
\mathrm{Nt} & =\text { Jumlah ikan yang hidup pada akhir pemeliharaan (ekor) } \\
\mathrm{No} & =\text { Jumlah ikan pada awal pemeliharaan (ekor) }
\end{array}
$$

\section{Laju Pertumbuhan Panjang Spesifik (LPPS)}

Laju pertumbuhan panjang spesifik dihitung dengan menggunakan rumus bedasarkan kutipan (Asma et al, 2016), yaitu:

$$
L P P S=\frac{\operatorname{InLt}-\operatorname{InLo}}{t} \times 100 \%
$$

Keterangan:

LPPS = Laju pertumbuhan panjang spesifik (\%)

Lt = Panjang rata-rata ikan pada akhir perlakuan $(\mathrm{cm})$

Lo $\quad=$ Panjang rata-rata ikan pada awal perlakuan $(\mathrm{cm})$ 
$\mathrm{t}=$ Periode pemeliharaan (hari)

\section{Laju Pertumbuhan Bobot Spesifik (LPBS)}

Laju pertumbuhan bobot spesifik dihitung dengan menggunakan rumus berdasarkan kutipan (Asma et al, 2016), yaitu:

$$
L P B S=\frac{\operatorname{In} W t-\operatorname{In} W o}{t} \times 100 \%
$$

Keterangan:

$$
\begin{array}{ll}
\text { LPBS } & =\text { Laju pertumbuhan bobot spesifik }(\%) \\
\mathrm{Wt} & =\text { Bobot rata-rata pada akhir perlakuan (gram) } \\
\mathrm{Wo} & =\text { Bobot rata-rata pada awal perlakuan (gram) } \\
\mathrm{t} & =\text { Periode pemeliharaan (hari) }
\end{array}
$$

\section{Rasio Konversi Pakan (RKP)}

Rasio konversi pakan (RKP) atau feeding conversion rate (FCR) pada benih lele selama pemeliharaan dihitung menggunakan rumus berdasarkan kutipan Hidayat (2013), yaitu:

$$
R K P=\frac{f}{B t+B m-B 0}
$$

Keterangan:

$$
\begin{array}{ll}
\mathrm{F} & =\text { Jumlah pakan (gram) } \\
\mathrm{Bt} & =\text { Biomassa ikan saat terakhir perlakuan (gram) } \\
\mathrm{Bm} & =\text { Biomassa ikan yang mati saat perlakuan (gram) } \\
\mathrm{B} 0 & =\text { Biomassa ikan pada saat awal perlakuan (gram) }
\end{array}
$$

\section{pH Air}

Asam adalah zat yang di dalan air melepaskan ion $\mathrm{H}+$ atau bisa dikatakan ion $\mathrm{H}+$ adalah pembawa sifat asam. Basa adalah senyawa yang bisa melepaskan ion hidroksida di dalam air $(\mathrm{OH})$. Jadi, ion $\mathrm{OH}$ adalah pembawa sifat basa menurut Arrhenius. Singkatan kata pH adalah "pondus Hydrogenium". pH berarti berat hydrogen. Derajat atau tingkatan keasaman larutan bergantung pada konsentrasi ion $\mathrm{H}+$ dalam larutan. Semakin besar ion $\mathrm{H}+$, maka semakin asam larutan tersebut. Nilai konsentrasi ion $\mathrm{H}+$ biasanya sangat kecil.

\section{Arduino UNO}

Arduino UNO adalah papan berbasis mikrokontroler pada ATmega328. Papan ini memiliki 14 pin input / output digital (6 pin di antaranya dapat digunakan sebagai output PWM), 6 input analog, osilator kristal 16 $\mathrm{MHz}$, koneksi USB, soket daya tombol reset. Pin ini berisi semua yang dibutuhkan untuk mendukung mikrokontroler, cukup sambungkan ke komputer dengan kabel USB atau sumber tegangan dapat diperoleh dari adaptor AC-DC atau baterai untuk menggunakannya [4][5].

\section{Sensor $\mathrm{pH}$}

Pengukur $\mathrm{pH}$ terdiri dari elektroda (probe pengukur) yang terhubung ke perangkat elektronik yang mengukur dan menampilkan nilai $\mathrm{pH}$. Prinsip kerja utama suatu $\mathrm{pH}$ meter terletak pada sensor probe yang berupa elektroda kaca dengan cara mengukur jumlah ion $\mathrm{H} 3 \mathrm{O}+$ dalam larutan. Ujung elektroda kaca adalah lapisan kaca berbentuk bola setebal $0,1 \mathrm{~mm}$. Bohlam ini dipasangkan dengan kaca non-konduktor memanjang atau silinder plastik. Inti sensor $\mathrm{pH}$ berada pada permukaan bola kaca yang memiliki kemampuan untuk menukar ion positif $(\mathrm{H}+)$ dengan larutan terukur [4]

\section{Bluetooth HC-06}

Bluetooth bekerja pada frekuensi radio, dan didalam bekerja tidak harus lineof sight seperti halnya infrared. Bluetooth frekuensi radio ISM 2.4 GHz. Kelebihan lain dari Bluetooth adalah kemampuannya untuk 
menembus dinding penghalang. Sedangkan jaraknya mencapai 10 meter dengan kecepatan transfer data mencapai 800 Kbps Namun Bluetooth tetap mempunyai kekurangan, yaitu interferensi dari frekuensi radio lainnya. Namun dari perkembangan teknologi, Bluetooth lebih banyak digunakan dari pada IrDa. Untuk itu, melalui integrasi dari Bluetooth pada perangkat smartphone Android dan hardware serta software yang digunakan, dihasilkan ide untuk merancang perangkat kendali peralatan elektronik berbasis Bluetooth pada smartphone Android [6].

\section{METODE PENELITIAN}

\section{Tahapan Penelitian}

Metodologi yang digunakan dalam pengembangan sistem. Pada penelitian ini diawali terlebih dahulu dengan observasi lapangan yang kemudian dilanjutkan dengan perancangan alat. Tahapan penelitian yang dilakkan diantaranya [7]:

1. Analisa Kebutuhan.

2. Perancangan Alat.

\section{Diagram Blok}

Untuk memudahkan dalam identifikasi kebutuhan protoipe pemandu parkir mobil dengan output suara manusia digambarkan dalam bentuk blok diagram. Blok diagram merupakan gambaran singkat dari perancangan suatu alat. Dari blok diagram akan menghasilkan suatu sistem yang dapat difungsikan dan dapat berkerja sesuai perancangan alat [8]. Pada gambar diagram blok di bawah ini menjelaskan tentang cara kerja alat secara keseluruhan mulai dari input, proses, hingga output. Dalam diagram blok ini hanya terdapat hubungan jalur antara blok-blok saja, tetapi tiap masing-masing blok terdapat komponen utama dan komponen pendukung. Pada gambar di bawah ini adalah gambar diagram blok dari mikrokontroler alat ini.

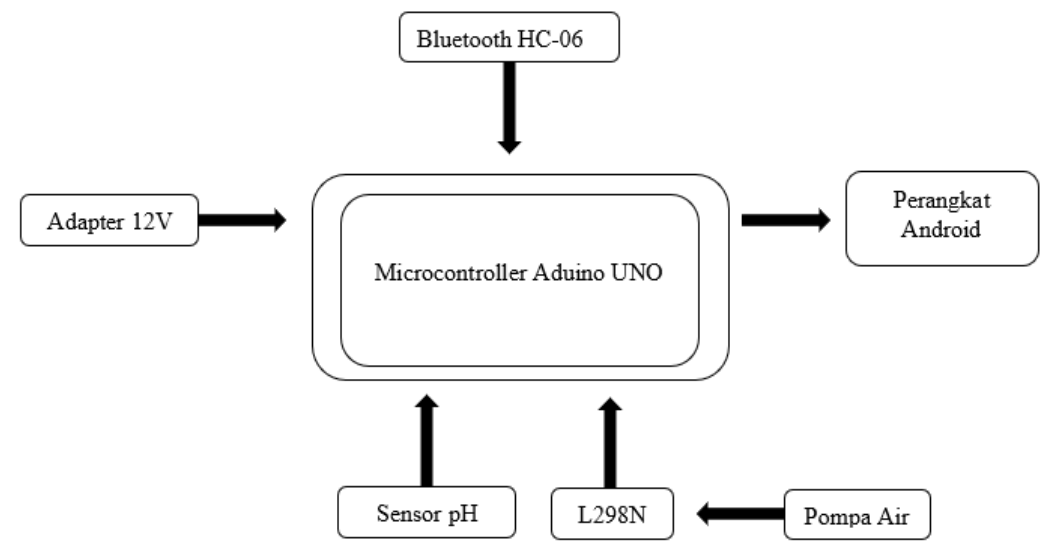

Gambar 1 Diagram Blok

Dari diagram blok di atas dapat dijelaskan masing-masing fungsi blok sebagai berikut :

1. Adaptor $12 \mathrm{v}$ digunakan untuk memberikan tegangan ke arduino dan komponen lainnya yang terhubung pada arduino.

2. Arduino Uno berfungsi sebagai pengatur dan pemroses masukan dari sensor $\mathrm{pH}$ sehingga dapat menghasilkan keluaran berupa angka.

3. Bluetooth HC-06 berfungsi untuk mengkoneksikan perangkat android ke Arduino UNO untuk mendapatkan data dari sensor $\mathrm{pH}$.

4. Perangkat Android digunakan untuk memonitoring $\mathrm{pH}$ meter air.

5. L298N berguna untuk mengatur 2 pompa yang akan digunakan untuk larutan asam dan basa.

6. Pompa air berfungsi untuk mengalirkan larutan Asam dan Basa Ketika kualitas $\mathrm{pH}$ air kolam berubah.

\section{Tahapan Pengembangan Alat}


Secara garis besar perancangan program terdiri dari empat tahap perancangan yaitu perancangan flowchart, penggunaan software Arduino IDE, dan perancangan alat dan bahan di dalam rangkainnya [9]. Sistem terdiri dari dua bagian besar, yaitu sebuah aplikasi perangkat lunak yang akan digunakan untuk sistem pengontrolan berbasis android dan sebuah sistem perangkat keras yang berperan dalam sisi mekanisme sistem [10].

\section{Perancangan Keseluruhan Alat}

Perancangan rangkaian keseluruhan alat terdiri dari empat elemen penting yang saling terintegrasi. Elemen-elemen penting tersebut yaitu rangkaian input, rangkaian proses, rangkaian output dan juga software program yang saling terintegrasikan. Rangkaian yang terdiri dari komponen-komponen elektronika baik berupa input atau output yang dibutuhkan oleh mikrokontroler agar dapat berfungsi dengan baik. Rangkaian keseluruhan alat dapat dilihat pada gambar berikut :

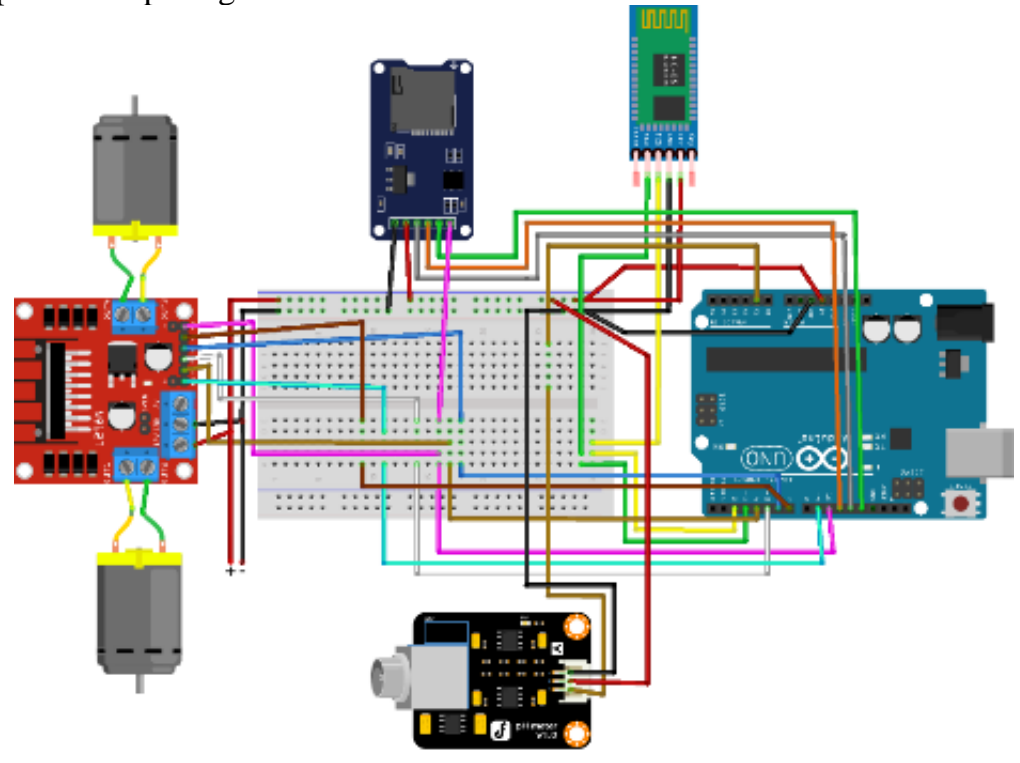

Gambar 2 Perancangan Seluruh Alat

\section{HASIL DAN PEMBAHASAN}

Disini penulis melakukan pengujian alat pengendalian kualitas air pada sebuah box yang berukuran panjang $73 \mathrm{~cm}$, lebar $41 \mathrm{~cm}$ dan tinggi $28 \mathrm{~cm}$. Didalam box berisi air 25 liter dan ikan lele jenis mutiara sebanyak 15 ekor. Pengujian alat dilakukan selama 5 jam untuk mengetahui cara kerja dan proses pengendalian air didalam box tersebut, penulis juga menggunakan larutan Asam dan Basa untuk menunjang pengendalian kualitas air. Menggunakan larutan Asam dan Basa sebanyak 2 botol dengan masing masing botol berukuran $1000 \mathrm{ml}$. Selama jangka waktu 5 jam penulis mendapatkan data dari hasil pengamatan kerja alat pengendali kualitas air dapat dilihat pada tabel berikut:

Tabel 1 Hasil Kinerja Alat Pengendali Kualitas Air

\begin{tabular}{|c|c|c|c|c|c|}
\hline \multirow{2}{*}{ Data } & \multirow{2}{*}{$\mathrm{pH}$ awal } & \multirow{2}{*}{$\mathrm{pH}$ netral (setpoint) } & \multicolumn{2}{|c|}{ Pompa } & \multirow{2}{*}{$\mathrm{pH}$ hasil } \\
\cline { 4 - 5 } & & & Asam & Basa & \\
\cline { 4 - 5 } & & & off & on & 6,11 \\
\hline 2 & 5,12 & $6,0-8,0$ & off & on & 7,44 \\
\hline 3 & 3,87 & $6,0-8,0$ & off & on & 6,02 \\
\hline
\end{tabular}




\begin{tabular}{|l|l|l|l|l|l|}
4 & 5,04 & $6,0-8,0$ & off & on & 6,06 \\
\hline 5 & 4,26 & $6,0-8,0$ & off & on & 6,19 \\
\hline
\end{tabular}

Dari hasil pengendalian kualitas air pada tabel 1 terdapat 4 data perubahan nilai $\mathrm{pH}$ air yang dapat dinetralkan kembali oleh alat pengendali kualitas air berikut penjelasan dari tabel 1.

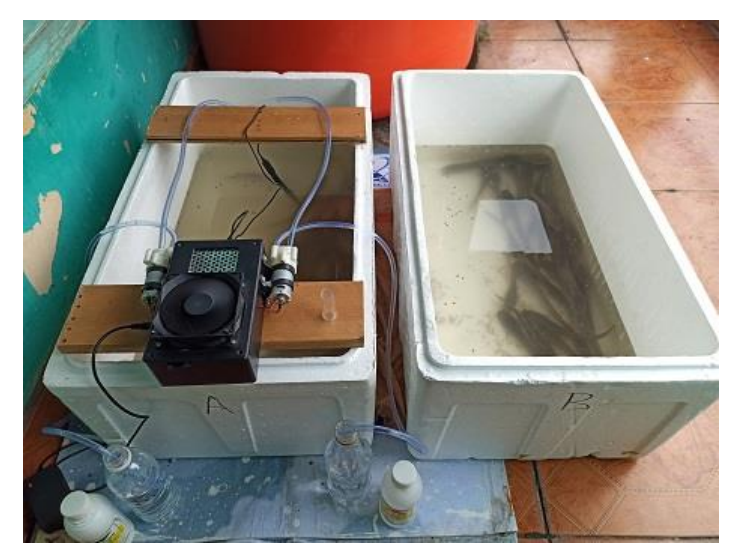

Gambar 3 Box Pengamatan Pertumbuhan

Dari gambar 8 terdapat 2 (dua) box yang berisi ikan lele jenis mutiara dengan masing masing box berisi 25 ekor ikan lele jenis mutiara yang berumur 1 bulan. Box A dilengkapi dengan alat pengendali kualitas air sedangkan Box B tanpa alat kendali kualitas air, pengamatan akan dihitung selama 1 minggu setelah ikan dimasukan kedalam box dengan tujuan untuk mengetahui pertumbuhan dan prilaku ikan dengan keadaan $\mathrm{pH}$ air yang terkontrol dan terkendali dengan box yang nilai $\mathrm{pH}$ airnya tanpa dikendalikan.

Dari hasil pengamatan antara Box A dan Box B, Berikut penjelasan dari Tabel 2:

Tabel 1 Data Hasil Pengamatan Box A Dengan Alat Kendali

\begin{tabular}{|c|c|c|c|}
\hline Hari & $\mathrm{pH}$ & prilaku & ukuran $(\mathrm{cm})$ \\
\hline 1 & 6.3 & agresif & 7 \\
\hline 2 & 6.4 & agresif & 7 \\
\hline 3 & 6.5 & agresif & 7.1 \\
\hline 4 & 6.4 & agresif & 7.2 \\
\hline 5 & 6.3 & agresif & 7.2 \\
\hline 6 & 6.8 & agresif & 7.2 \\
\hline 7 & 6.9 & tenang & 7.3 \\
\hline
\end{tabular}

Sedangkan perbedaan hasil pengamatan pertumbuhan ikan lele jenis mutiara antara Box A dan Box B dapat dilihat pada tabel 4.

Tabel 2 Data Hasil Pengamatan Box B Tanpa Alat Kendali

\begin{tabular}{|c|c|c|c|}
\hline Hari & $\mathrm{pH}$ & prilaku & ukuran $(\mathrm{cm})$ \\
\hline 1 & 6.3 & agresif & 7 \\
\hline 2 & 6 & agresif & 7 \\
\hline
\end{tabular}




\begin{tabular}{|l|l|l|l|}
3 & 5.8 & agresif & 7.1 \\
\hline 4 & 5.9 & tenang & 7.1 \\
\hline 5 & 4.8 & tenang & 7.1 \\
\hline 6 & 4.2 & tenang & 7.1 \\
\hline 7 & 4 & sangat tenang & 7.2 \\
\hline
\end{tabular}

Dari hasil pengamatan alata pengendali kualitas air, Box B yang tanpa menggunakan alat pengendali nilai $\mathrm{pH}$ air cendrung tidak stabil dan tidak berada pada kisaran nilai $\mathrm{pH}$ yang dibutuhkan ikan lele, sedangkan Box A dengan alat pengendali kualitas air masih terjadi perubahan nilai $\mathrm{pH}$ air tetapi dalam rentang yang kecil, alat pengendali kualitas air mampu menjada kestabilan nilai pH pada kisaran pH 6 sampi pH 7. Dari hasil kedua tabel Box A dan Box B terlihat perbedaan dari pertumbuhan dan perilaku ikan lele. Berikut perhitungan pertumbuhan ikan lele:

\section{Derajat Kelangsungan Hidup (SR)}

Jika dihitung menggunakan rumus SR maka hasil yang akan didapat sebagai berikut:

$$
S R=\left(\frac{N t}{N o}\right) \times 100 \%
$$

Box A dengan alat pengendali kualitas air nilai No adalah 25 ekor dan jumlah Nt adalah 25 ekor, jika jumlah awal pemeliharaan sampai akhir pemeliharaan berjumlah sama maka hasil SR adalah $100 \%$. Sedangkan pada Box B tanpa alat pengendali kualitas air nilai No berjumlah 25 ekor dan nilai Nt berjumlah 23 ekor, dari nilai Box B jumlah SR adalah $92 \%$ hal ini dikarenakan pada Box B kualitas air tidak terkendali dan terkontrol dengan baik sehingga membuat kelangsungan hidup ikan lele menjadi tidak stabil.

\section{Laju Pertumbuhan Panjang Spesifik (LPPS)} berikut:

Untuk perhitungan pertumbuhan panjang spesifik (LPPS) rumus yang akan digunakan sebagai

$$
L P P S=\frac{\operatorname{InLt}-\operatorname{InLo}}{t} \times 100 \%
$$

Pertumbuhan dari ikan yang ada pada Box A dengan alat pengendali kualitas air dapat dihitung dengan nilai InLo adalah $7 \mathrm{~cm}$, nilai InLt $7.3 \mathrm{~cm}$ dan nilai t 7 hari, nilai InLt dikurang dengan nilai InLo lalu dibagi dengan nilai t dan dikalikan $100 \%$ maka hasil nilai LPPS pada Box A adalah 0,04\%. Sedangkan pada Box B tanpa alat pengendali kualitas air nilai Inlt $7.2 \mathrm{~cm}$, nilai InLo $7 \mathrm{~cm}$ dan nilai t 7 hari, maka hasil perhitungan menggunakan rumus LPPS nilai yang dihasilkan Box B adalah sebesar $0,02 \%$.

\section{Kalibrasi pada Alat}

Kalibrasi pengontrol kualitas air dilakukan dengan membandingkannya dengan pengukur $\mathrm{pH}$ air digital, dimana penulis menggunakan larutan pH 7,2. Kalibrasi ini bertujuan untuk mengetahui apakah sensor probe $\mathrm{pH}$ mampu membaca nilai $\mathrm{pH}$ air serta pengukur $\mathrm{pH}$ digital dan untuk mengetahui berapa persen perbedaan atau error yang terjadi selama pengukuran. Berikut ini kalibrasi alat pengendali kualitas air dengan larutan $\mathrm{pH} 7$ yang sudah diukur dengan alat yang sudah tertuji sebelumnya. 


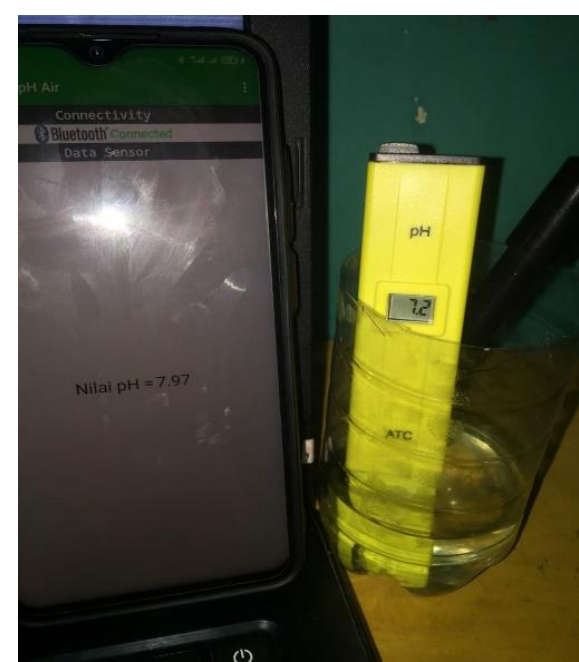

Gambar 4 Foto proses kalibrasi

Tabel 5 Hasil Kalibrasi Alat

\begin{tabular}{|c|c|c|}
\hline No & Kualitas $\mathrm{pH}$ & Hasil Kalibrasi \\
\hline 1 & 7.2 & 7.9 \\
\hline 2 & 7.2 & 7.2 \\
\hline 3 & 7.2 & 7 \\
\hline 4 & 7.2 & 6.9 \\
\hline
\end{tabular}

Dari tabel 5 diatas nilai pH yang dihasilkan dari kalibrasi alat dengan menggunakan nilai pH air 7.2 selama 4 kali percobaan dan menghasilkan nilai $\mathrm{pH}$ yang menurun, terdapat beberapa $0.01 \%$ error data dapat disimpulkan bahwa pembacaan sensor lebih dominan ke larutan asam.

\section{SIMPULAN}

Kesimpulan yang dapat diambil dari hasil penelitian adalah :

1. Pertumbuhan ikan lele dapat terbantu dengan adanya alat pengendi kualitas air ini, tetapi pada penelitian ini selisih data yang dihasilkan masih sangat kecil karena waktu pada saat pengamatan pertumbuhan ikan lele sangat singkat.

2. Alat pengendali kualitas air dapat menjaga dengan baik kualitas air, namun pompa larutan terkadang terlalu banyak mengalirkan larutan sehingga dapat mengakibatkan pompa bekerja dua kali.

3. Akurasi sensor $\mathrm{pH}$ cenderung lebih sensitif pada larusan asam.

\section{DAFTAR PUSTAKA}

[1] A. Qalit and A. Rahman, "Rancang Bangun Prototipe Pemantauan Kadar Ph Dan Kontrol Suhu Serta Pemberian Pakan Otomatis Pada Budidaya Ikan Lele Sangkuriang Berbasis Iot," J. Karya Ilm. Tek. Elektro, vol. 2, no. 3, pp. 8-15, 2017.

[2] R. Ardyanti, D. D. Nindarwi, L. A. Sari, and P. D. Wulan Sari, "Manajemen Pembenihan Lele Mutiara (Clarias Sp.) Dengan Aplikasi Probiotik Di Unit Pelayanan Teknis Pengembangan Teknologi Perikanan Budidaya (Upt Ptpb) Kepanjen, Malang, Jawa Timur," J. Aquac. Fish Heal., vol. 7, no. 2, p. 84, 2018, doi: 10.20473/jafh.v7i2.11254.

[3] M. Ikhsan, M. Muhsin, and P. Patang, "Pengaruh Variasi Suhu Pengering Terhadap Mutu 
Dendeng Ikan Lele Dumbo (Clarias gariepinus)," J. Pendidik. Teknol. Pertan., vol. 2, no. 2, p. 114, 2018, doi: 10.26858/jptp.v2i2.5166.

[4] S. Samsugi and A. Suwantoro, "Pemanfaatan Peltier dan Heater Sebagai Alat Pengontrol Suhu Air Pada Bak Penetasan Telur Ikan Gurame," pp. 295-299.

[5] R. Dikky Auliya Saputra, Amarudin, "Rancang Bangun Alat Pemberi Pakan Ikan Otomatis Menggunakan Pewaktu," J. Ilm. Tek. Pertan., vol. 7, no. 1, pp. 1-76, 2015.

[6] P. RAHMIATI, G. FIRDAUS, and N. FATHORRAHMAN, "Implementasi Sistem Bluetooth menggunakan Android dan Arduino untuk Kendali Peralatan Elektronik," ELKOMIKA J. Tek. Energi Elektr. Tek. Telekomun. Tek. Elektron., vol. 2, no. 1, p. 1, 2015, doi: 10.26760/elkomika.v2i1.1.

[7] K. Pindrayana, R. Indra Borman, B. Prasetyo, and S. Samsugi, "Prototipe Pemandu Parkir Mobil Dengan Output Suara Manusia Mengunakan Mikrokontroler Arduino Uno," CIRCUIT J. Ilm. Pendidik. Tek. Elektro, vol. 2, no. 2, pp. 71-82, 2018, doi: 10.22373/crc.v2i2.3705.

[8] Ikhsan and H. Kurniawan, "Implementasi Sistem Kendali Cahaya Dan Sirkulasi Udara Ruangan Dengan Memanfaatkan Pc Dan Mikrokontroler Atmega8," J. TEKNOIF, vol. 3, no. 1, pp. 12-19, 2015.

[9] S. D. R. I Komang, "Rancang Bangun Sistem Pengunci Loker Otomatis Dengan Kendali Akses Menggunakan Rfid Dan Sim 800L," J. Ilm. Mhs. Kendali dan List., vol. 1, no. 1, pp. 33-41, 2020.

[10] A. Mulyanto, Y. A. Nurhuda, and I. Khoirurosid, "Sistem Kendali Lampu Rumah Menggunakan Smartphone Android," J. Teknoinfo, vol. 11, no. 2, p. 48, 2017, doi: 10.33365/jti.v11i2.28. 